\title{
Carbon dioxide assist for non-aqueous sodium-oxygen batteries
}

\author{
Shyamal K. Das, Shaomao Xu, Lynden A. Archer* \\ School of Chemical and Biomolecular Engineering, Cornell University, NY 14853, USA
}

\section{A R T I C L E I N F O}

\section{Article history:}

Received 3 September 2012

Received in revised form 2 October 2012

Accepted 27 October 2012

Available online 1 November 2012

\section{Keywords:}

Sodium-air battery

Magnesium-air battery

\begin{abstract}
A B S T R A C T
We report a novel non-aqueous $\mathrm{Na}$-air battery that utilizes a gas mixture of $\mathrm{CO}_{2}$ and $\mathrm{O}_{2}$. The battery exhibits a high specific energy of $6500-7000 \mathrm{Whkg}^{-1}$ (based on the carbon mass) over a range of $\mathrm{CO}_{2}$ feed compositions. The energy density achieved is higher, by $200 \%$ to $300 \%$, than that obtained in pure oxygen. Ex-situ FTIR and XRD analysis reveal that $\mathrm{Na}_{2} \mathrm{O}_{2}, \mathrm{Na}_{2} \mathrm{C}_{2} \mathrm{O}_{4}$ and $\mathrm{Na}_{2} \mathrm{CO}_{3}$ are the principal discharge products. The $\mathrm{Na}-\mathrm{CO}_{2} / \mathrm{O}_{2}$ and $\mathrm{Mg}-\mathrm{CO}_{2} / \mathrm{O}_{2}$ battery platforms provide a promising, new approach for $\mathrm{CO}_{2}$ capture and generation of electrical energy.
\end{abstract}

(C) 2012 Elsevier B.V. All rights reserved.

\section{Introduction}

Growing interest in electrochemical energy storage for transportation and grid storage has resulted in an intensive search for alternative energy storage technologies that offer specific energies above those achievable $\left(\sim 200 \mathrm{Whkg}^{-1}\right)$ with state-of-the-art lithium-ion batteries. More than a decade of research into such storage platforms has helped define the magnitude of the challenges that must be overcome for lithium-ion batteries to achieve specific energies in the 500-700 $\mathrm{Whkg}^{-1}$ range [1]. In this context, metal-air batteries are gaining focus because of their exceptionally high specific energies $[2,3]$. Among the various metal-air batteries, the $\mathrm{Li}$-air and $\mathrm{Zn}$-air technologies have attracted most attention.

An air battery utilizing $\mathrm{Na}$ as anode is attractive because of the high earth abundance, modest cost, and relatively high electrode potential $\left(-2.71 \mathrm{~V}\right.$ vs SHE) that may be achieved. Coupled with $\mathrm{O}_{2}$, $\mathrm{Na}$ has the ability to deliver a specific energy of $1600 \mathrm{Whkg}^{-1}$ $\left(2 \mathrm{Na}^{+}+\mathrm{O}_{2}+2 \mathrm{e}^{-} \rightarrow \mathrm{Na}_{2} \mathrm{O}_{2}\right.$ at $2.33 \mathrm{~V}$; estimated based on the weight of both $\mathrm{Na}$ and $\mathrm{O}_{2}$ consumed). Until 2011, the potential of the $\mathrm{Na}-\mathrm{O}_{2}$ couple remained less explored, in comparison to the $\mathrm{Li}-\mathrm{O}_{2}$ battery. A report by Peled et al. demonstrated a $\mathrm{Na}-\mathrm{O}_{2}$ cell based on liquid $\mathrm{Na}$ in combination with polymer electrolytes and operated at $100{ }^{\circ} \mathrm{C}$ [4]. Fu et al. proposed an alternative $\mathrm{Na}-\mathrm{O}_{2}$ cell configuration that operates at room temperature in ethylene carbonate/dimethyl carbonate as electrolyte [5]. They reported a stable discharge plateau at $2.3 \mathrm{~V}$, corresponding to $\mathrm{Na}_{2} \mathrm{O}_{2}$ formation.

$\mathrm{CO}_{2}$ is a greenhouse gas and has been implicated in global climate change [6]. A variety of chemical and physical methodologies are under development for capturing and sequestering the thousands of metric tons of the gas emitted per annum [6-8]. A metal-air battery that utilizes a mixed fuel of $\mathrm{CO}_{2}$ and $\mathrm{O}_{2}$ provides a potentially novel

\footnotetext{
* Corresponding author. Tel.: +1 607255 4420; fax: +1 6072559166 .

E-mail address: laa25@cornell.edu (L.A. Archer).
}

platform for electrical energy generation and carbon capture [9]. Recently, researchers at Toyota reported that incorporation of $\mathrm{CO}_{2}$ with $\mathrm{O}_{2}$ improves the energy density of a $\mathrm{Li}-\mathrm{O}_{2}$ battery [10], indicating that there may be other benefits for incorporating $\mathrm{CO}_{2}$ in other metal-air batteries.

Herein, we report novel Na- $\mathrm{CO}_{2} / \mathrm{O}_{2}$ and $\mathrm{Mg}-\mathrm{CO}_{2} / \mathrm{O}_{2}$ batteries operated at room temperature utilizing tetraglyme and an ionic liquid as electrolyte. Unlike the $\mathrm{Li}-\mathrm{O}_{2} / \mathrm{CO}_{2}$ battery [10], which specifically aims to use $\mathrm{CO}_{2}$ to enhance the energy density of the $\mathrm{Li}-\mathrm{O}_{2}$ cell, the current work focuses on metal- $\mathrm{CO}_{2} / \mathrm{O}_{2}$ batteries as platforms for $\mathrm{CO}_{2}$ capture in a technology that also produces electrical energy. Both of these goals are met using a "primary" battery, i.e. one that removes/concentrates $\mathrm{CO}_{2}$ from an effluent gas mixture, and therefore does not require the cathode reactions to be reversible. While the economics of such a battery based on lithium anode may be impractical, they can become viable for anodes based on a variety of earth abundant materials such as $\mathrm{Na}, \mathrm{Mg}, \mathrm{Al}, \mathrm{Zn}, \mathrm{Ca}, \mathrm{Cu}$, and $\mathrm{Fe}$ [11]. As with other $\mathrm{CO}_{2}$ capture technologies, we envision metal- $-\mathrm{CO}_{2} / \mathrm{O}_{2}$ batteries as the first step in a systematic program for $\mathrm{CO}_{2}$ capture and sequestration, which ultimately uses chemical, biological, or geological approaches for $\mathrm{CO}_{2}$ sequestration.

\section{Experimental}

The investigated $\mathrm{Na}-\mathrm{CO}_{2} / \mathrm{O}_{2}$ battery configuration is similar to our recently reported $\mathrm{Li}-\mathrm{O}_{2}$ battery [12]. The air cathode consists of $90 \%$ Super P (TIMCAL) carbon and 10\% PVDF binder. Mechanically perforated coin cells were used for electrochemical experiments. $1 \mathrm{M}$ $\mathrm{NaClO}_{4} /$ tetraethylene glycol dimethylether and $0.75 \mathrm{M} \mathrm{NaCF}_{3} \mathrm{SO}_{3} /$ 1-ethyl-3-methyl imidazolium trifluromethanesulfonate (IL) were used as electrolytes. The cells were assembled in an argon-filled glove box. Required concentrations of $\mathrm{CO}_{2}$ and $\mathrm{O}_{2}$ were premixed in a chamber at $1 \mathrm{~atm}$ before introducing the gas feed into the battery chamber. Galvanostatic experiments were performed at $25{ }^{\circ} \mathrm{C}$ and at 
a current density of $70 \mathrm{mAg}^{-1}$. The porous carbon electrode dimension is $1.95 \mathrm{~cm}^{2}$ with typical carbon loading of $0.76-1.28 \mathrm{mg} \mathrm{cm}^{-2}$ and thickness of $5 \mu \mathrm{m}$. AC impedance measurements were conducted at frequencies from $100 \mathrm{kHz}$ to $100 \mathrm{mHz}$ at $10 \mathrm{mV}$ bias voltage. Ex-situ TEM, FTIR and XRD analyses used discharged electrodes that were vacuum dried.

\section{Results and discussion}

Fig. 1 reports the galvanostatic discharge profiles of $\mathrm{Na}-\mathrm{CO}_{2} / \mathrm{O}_{2}$ cells operated under various concentrations of $\mathrm{O}_{2}$ and $\mathrm{CO}_{2}$. Fig. $1 \mathrm{~A}$ and $\mathrm{B}$ correspond, respectively, to cells using ionic liquid and tetraglyme-based electrolytes. Under a $100 \% \mathrm{O}_{2}$ environment, the two varieties of $\mathrm{Na}$-air cells exhibit discharge capacities of $1315 \mathrm{mAhg}^{-1}$ and $1390 \mathrm{mAhg}^{-1}$, respectively (estimated based on carbon mass). Unlike Fu et al. [5], the discharge profiles with pure $\mathrm{O}_{2}$ feed show a less well-defined voltage plateau at $2.3 \mathrm{~V}$. This difference might be attributed to the electrolytes and air cathode employed in our studies, since the current rates are similar [12]. The $\mathrm{Na}-\mathrm{CO}_{2} / \mathrm{O}_{2}$ cells also show low discharge capacities of 183 and $173 \mathrm{mAhg}^{-1}$ under pure $\mathrm{CO}_{2}$ environment. Sluggish reaction kinetics between $\mathrm{Na}^{+}$ions and $\mathrm{CO}_{2}$ at room temperature is anticipated [9], which may explain the latter observation. Remarkably, the discharge capacities of both the IL and tetraglyme based $\mathrm{Na}-\mathrm{CO}_{2} / \mathrm{O}_{2}$ cells based on feed streams containing $40 \%$ and $63 \% \mathrm{CO}_{2}$ are respectively 3500 and $2882 \mathrm{mAhg}^{-1}$; an increase of 2.6 and 2.1 times compared to the
Na-100\% $\mathrm{O}_{2}$ case. Fig. $1 \mathrm{C}$ reports the relative discharge capacities as a function of $\mathrm{CO}_{2}$ concentration. The variation in capacity depends on the chemical composition of the electrolytes, but displays a similar trend for the tetraglyme- and IL-based electrolytes, with the highest discharge capacities observed at intermediate $\mathrm{CO}_{2}$ compositions. It demonstrates that the specific energy of a $\mathrm{Na}$-air cell can be significantly enhanced, by factors of 2 to 3 , by introducing optimized concentrations of $\mathrm{CO}_{2}$. It is also apparent that the optimal ratio of $\mathrm{CO}_{2} / \mathrm{O}_{2}$ for the largest discharge capacity lies between $40 \%$ and $70 \% \mathrm{CO}_{2}$ and depends on the composition of the electrolyte. The optimal $\mathrm{CO}_{2} / \mathrm{O}_{2}$ feed composition is also expected to be a function of temperature [12].

It is also apparent from Fig. $1 \mathrm{~A}$ and B that irrespective of electrolyte, there is an improvement in the quality of the discharge voltage profile upon introduction of $\mathrm{CO}_{2}$ to the cells. A plateau voltage around $2-2.2 \mathrm{~V}$ is observed in both cases. Fig. 1D shows discharge profiles obtained from two identical tetraglyme-based Na-air cells operated under $\mathrm{O}_{2}(37 \%) / \mathrm{CO}_{2}(63 \%)$ concentrations. A polarization of $\sim 500 \mathrm{mV}$ is observed between the cells. To understand the origin of this effect, two identical Na-air cells were assembled and stored separately in $\mathrm{Ar}$ and $\mathrm{O}_{2} / \mathrm{CO}_{2}$ environments. AC impedance spectra of the cells were measured at various time periods at open circuit conditions as shown in Fig. $1 \mathrm{E}$ and $\mathrm{F}$. The results for the Ar-stored $\mathrm{Na}$-air cell suggest that the electrolyte in contact with reactive Na metal forms a stable electrode/ electrolyte interface over time. It is also evident from the figure that the $\mathrm{Na}$-air cell stored in $\mathrm{O}_{2} / \mathrm{CO}_{2}$ exhibits less interfacial stability. As
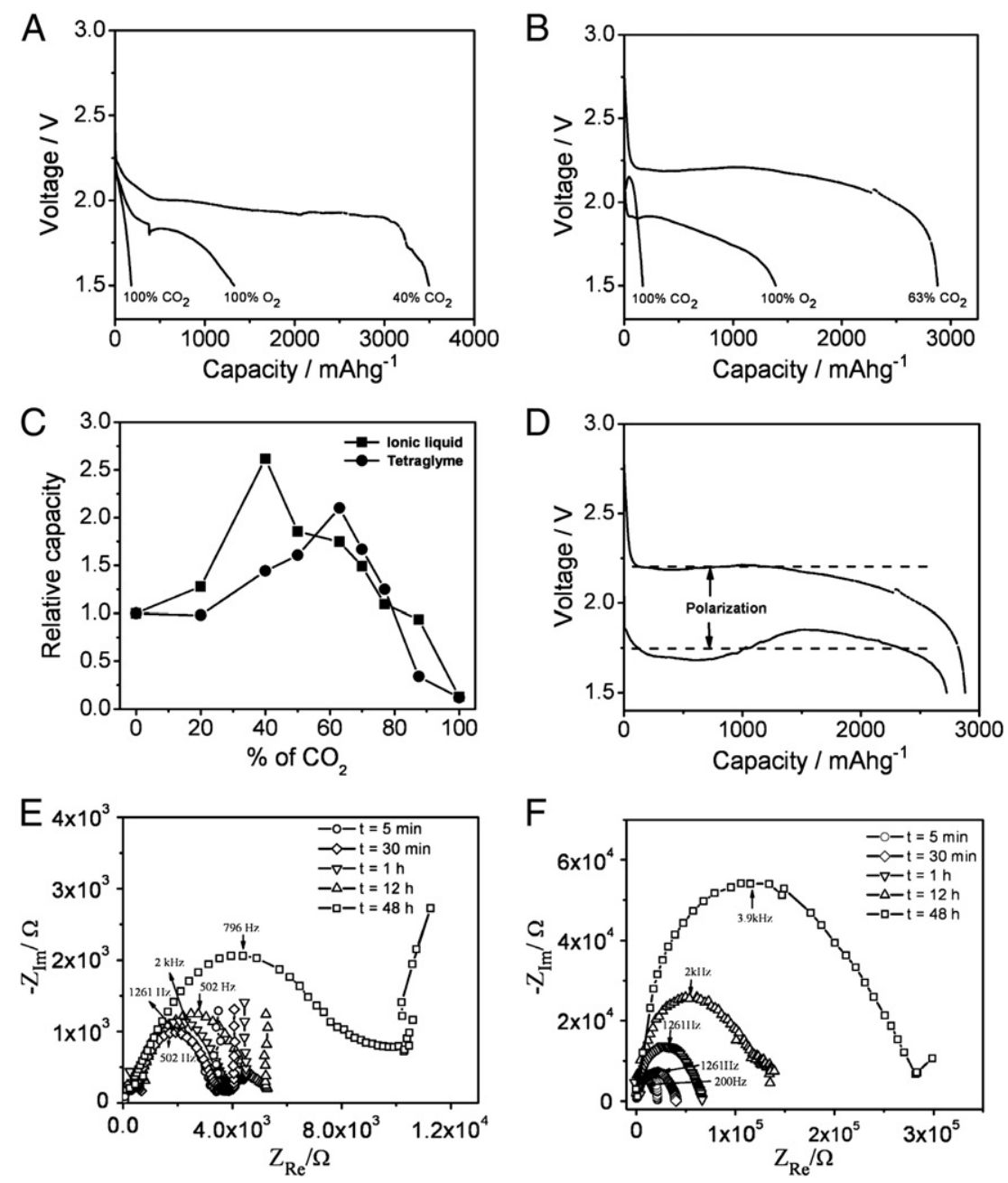

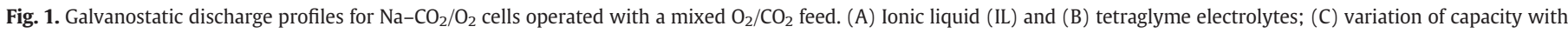

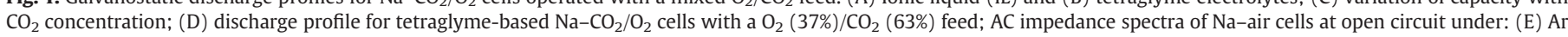
and $(\mathrm{F}) \mathrm{O}_{2} / \mathrm{CO}_{2}$ atmospheres. 
the $\mathrm{Na}$ and carbon electrodes were separated by a micrometer thick separator and no gas protective layer covers the $\mathrm{Na}$ anode, it is anticipated that $\mathrm{O}_{2} / \mathrm{CO}_{2}$ diffuse and react with $\mathrm{Na}$ and the reaction products induce an increase in interfacial resistance at the electrode/electrolyte interface. Because a thicker electrode/electrolyte interface is anticipated for the cells stored in the $\mathrm{O}_{2} / \mathrm{CO}_{2}$ environment, more energy is required for the electrochemically generated $\mathrm{Na}^{+}$ions to migrate to the cathode oxidant, which would cause the observed cell polarization.

To obtain deeper insights into the overall electrochemistry and role of $\mathrm{CO}_{2}$ the discharged carbon electrodes were harvested and investigated by TEM, XRD, and FTIR spectroscopy. Ex-situ TEM images (Fig. 2B and C), indicate that the porous carbon electrodes are filled with discharge products. Fig. 2D shows that additional X-ray diffraction peaks emerge in every case (Fig. 2Db-d). The peaks can be indexed to crystalline phase of $\mathrm{Na}_{2} \mathrm{O}_{2}$ (ICDD no. 083-0597) in case of $\mathrm{Na}-100 \% \mathrm{O}_{2}$ cells (Fig. 2D). Remarkably, however, no signature of
$\mathrm{Na}_{2} \mathrm{O}_{2}$ is found in electrodes from the $\mathrm{O}_{2} / \mathrm{CO}_{2}$ mixed gas feed. Instead, diffraction peaks for $\mathrm{Na}_{2} \mathrm{CO}_{3}$ (ICDD no. 075-6816) and $\mathrm{Na}_{2} \mathrm{C}_{2} \mathrm{O}_{4}$ (ICDD no. 075-3639) are observed. Additionally, while $\mathrm{Na}_{2} \mathrm{CO}_{3}$ and $\mathrm{Na}_{2} \mathrm{C}_{2} \mathrm{O}_{4}$ coexist for the tetraglyme based $\mathrm{Na}-\mathrm{O}_{2} / \mathrm{CO}_{2}$ cells (Fig. $2 \mathrm{Dd}$ ), $\mathrm{Na}_{2} \mathrm{C}_{2} \mathrm{O}_{4}$ is the dominant phase for cells using the IL electrolyte (Fig. 2D). Ex-situ FTIR supports these observations (Fig. 2E and F). Peaks at $1652 \mathrm{~cm}^{-1}$ and $877 \mathrm{~cm}^{-1}$ (Fig. 2Ec and Fc, \$) can be assigned to $\mathrm{Na}_{2} \mathrm{O}_{2}$ [13]. Peaks at $1632 \mathrm{~cm}^{-1}$ and $775 \mathrm{~cm}^{-1}$ (Fig. 2Ed, \#) respectively correspond to antisymmetric stretching and in plane modes of $\mathrm{O}-\mathrm{C}-\mathrm{O}$ in oxalates. IR peaks at $1426 \mathrm{~cm}^{-1}$ and $879 \mathrm{~cm}^{-1}$ (Fig. $2 \mathrm{Fd}$, *) correspond to $\mathrm{O}-\mathrm{C}=\mathrm{O}$ vibrations in carbonates.

The XRD and FTIR results suggest that the following electrochemical reaction may occur in cells that employ pure $\mathrm{O}_{2}: \mathrm{O}_{2}+2 \mathrm{e}^{-}+$ $2 \mathrm{Na}^{+} \rightarrow \mathrm{Na}_{2} \mathrm{O}_{2}$ [5]. The processes by which $\mathrm{Na}_{2} \mathrm{CO}_{3}$ and $\mathrm{Na}_{2} \mathrm{C}_{2} \mathrm{O}_{4}$ are formed for $\mathrm{O}_{2} / \mathrm{CO}_{2}$ mixed gas feed are likely more complex. Electrochemical reduction of $\mathrm{O}_{2}$ and $\mathrm{CO}_{2}$ is known to involve complicated
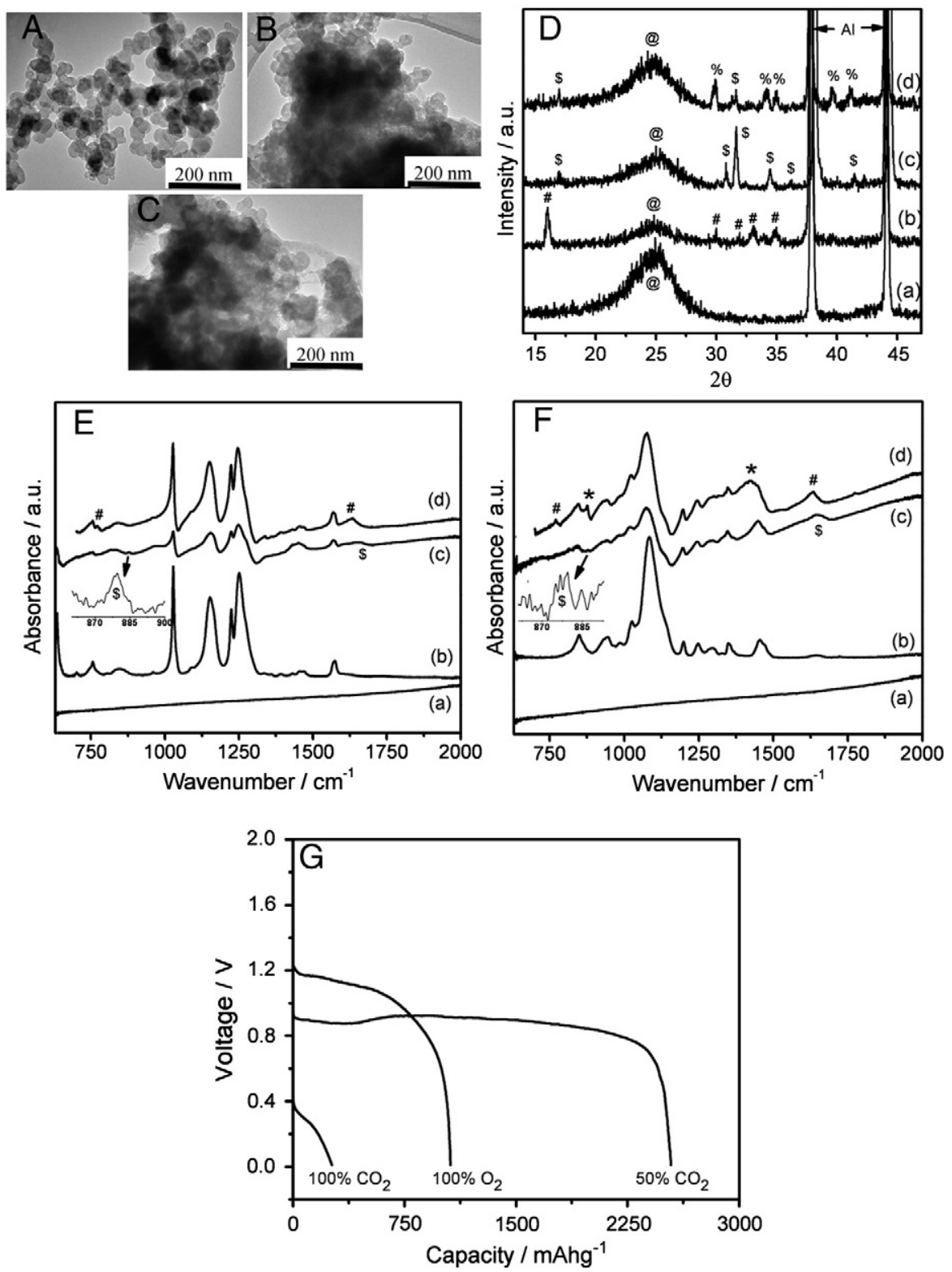

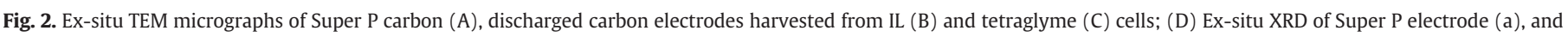

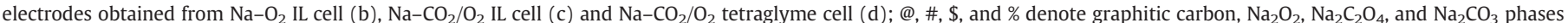

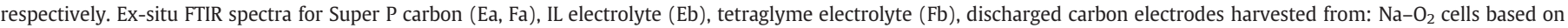

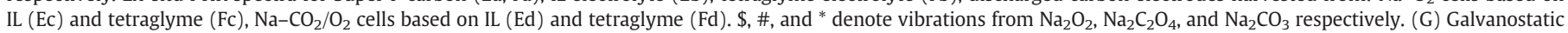
discharge curves for $\mathrm{Mg}$-air cells. 
elementary reactions and also depends on the solvent and electrode material $[14,15]$. It should be noted nonetheless that the fact that only $\mathrm{Na}_{2} \mathrm{C}_{2} \mathrm{O}_{4}$ forms in IL based electrolytes, whereas both $\mathrm{Na}_{2} \mathrm{CO}_{3}$ and $\mathrm{Na}_{2} \mathrm{C}_{2} \mathrm{O}_{4}$ coexist in tetraglyme cells indicates that the reactions are not hopelessly complex. Various research groups have reported on the electrochemical reduction of $\mathrm{O}_{2}$ and $\mathrm{CO}_{2}[14,15]$. Based on the reported results and the observations above, we propose the following preliminary view of the reaction mechanisms for the $\mathrm{Na}-\mathrm{O}_{2} / \mathrm{CO}_{2}$ cell.

Mechanism 1 [10,13]:

$$
\begin{aligned}
& 4 \mathrm{O}_{2}+4 \mathrm{e}^{-} \rightarrow 4 \mathrm{O}_{2}^{\cdot-} \\
& \mathrm{O}_{2}^{\cdot-}+\mathrm{CO}_{2} \rightarrow \mathrm{CO}_{4}^{\cdot-} \\
& \mathrm{CO}_{4}^{\cdot-}+\mathrm{CO}_{2} \rightarrow \mathrm{C}_{2} \mathrm{O}_{6}^{\cdot-} \\
& \mathrm{C}_{2} \mathrm{O}_{6}^{--}+\mathrm{O}_{2}^{\cdot-} \rightarrow \mathrm{C}_{2} \mathrm{O}_{6}^{2-}+\mathrm{O}_{2} \\
& \mathrm{C}_{2} \mathrm{O}_{6}^{-}+2 \mathrm{O}_{2}^{\cdot-}+4 \mathrm{Na}^{+} \rightarrow 2 \mathrm{Na}_{2} \mathrm{CO}_{3}+2 \mathrm{O}_{2} .
\end{aligned}
$$

Mechanism 2: The $\mathrm{O}_{2}$ electroreduction reactions in aprotic organic solvents are as follows. (i) $\mathrm{O}_{2}+\mathrm{e}^{-} \rightarrow \mathrm{O}_{2}^{--}$and (ii) $\mathrm{O}_{2}+2 \mathrm{e}^{-} \rightarrow \mathrm{O}_{2}^{2-}$ [14]. Since $\mathrm{Na}_{2} \mathrm{C}_{2} \mathrm{O}_{4}$ is a discharge product, the following reactions are also possible:

$\mathrm{CO}_{2}+\mathrm{O}_{2}^{2-} \rightarrow \mathrm{CO}_{4}^{2-}$

$\mathrm{CO}_{4}^{2-}+\mathrm{CO}_{2}+2 \mathrm{Na}^{+} \rightarrow \mathrm{Na}_{2} \mathrm{C}_{2} \mathrm{O}_{4}+\mathrm{O}_{2}$.

Mechanism 3: The $\mathrm{CO}_{2}$ electroreduction reactions in aprotic organic solvents are as follows. (i) $2 \mathrm{CO}_{2}+2 \mathrm{e}^{-} \rightarrow \mathrm{C}_{2} \mathrm{O}_{4}^{2-}$ and (ii) $2 \mathrm{CO}_{2}+2 \mathrm{e}^{-} \rightarrow$ $\mathrm{CO}_{3}^{2-}+\mathrm{CO}$ [15]. Since $\mathrm{Na}-100 \% \mathrm{CO}_{2}$ cells also show some capacity, a direct reaction with $\mathrm{CO}_{2}$ must also be possible:

$\mathrm{C}_{2} \mathrm{O}_{4}^{2-}+2 \mathrm{Na}^{+} \rightarrow \mathrm{Na}_{2} \mathrm{C}_{2} \mathrm{O}_{4}$ and $\mathrm{CO}_{3}^{2-}+2 \mathrm{Na}^{+} \rightarrow \mathrm{Na}_{2} \mathrm{CO}_{3}$.

Considering a typical discharge voltage plateau at $\sim 2 \mathrm{~V}$ in Na-CO$/ \mathrm{O}_{2}$ cells and based on the above mechanisms, it appears that mechanisms 1 and 2 are the most probable since mechanism 3 would lead to a cell voltage of $\sim 200 \mathrm{mV}$, with mechanism 2 dominating in the IL-based electrolyte. More careful electrochemical experiments are ongoing to evaluate and refine these hypotheses.

The same ideas would lead one to expect that electrochemical properties of non-aqueous primary metal-air cells based on other earth-abundant metals, e.g. $\mathrm{Mg}$, may also be enhanced by introduction of $\mathrm{CO}_{2}$. To evaluate this idea, we assembled a $\mathrm{Mg}$-air cell as a proof of concept. $1 \mathrm{M} \mathrm{Mg}\left(\mathrm{ClO}_{4}\right)_{2}$-propylene carbonate is used as electrolyte. As illustrated in Fig. $2 \mathrm{G}$, the $\mathrm{Mg}$-air cell shows a discharge voltage plateau of $\sim 0.9 \mathrm{~V}$ and close to a factor of $250 \%$ enhancement in specific energy with introduction of $50 \% \mathrm{CO}_{2}$, underscoring its promise.

\section{Conclusions}

In summary, we investigated a primary non-aqueous $\mathrm{Na}-\mathrm{CO}_{2} / \mathrm{O}_{2}$ battery as a dual platform for converting a $\mathrm{CO}_{2}$-rich gas stream to electrical energy and for capturing the $\mathrm{CO}_{2}$. The $\mathrm{Na}$-air battery shows enhancements of 200 to $300 \%$ when a mixture of $\mathrm{CO}_{2} / \mathrm{O}_{2}$ gas with high $\mathrm{CO}_{2}$ content is used as fuel. Preliminary postmortem structural analysis indicates that $\mathrm{Na}_{2} \mathrm{CO}_{3}$ and $\mathrm{Na}_{2} \mathrm{C}_{2} \mathrm{O}_{4}$ are formed. We further show that metal-air batteries based on other, earth-abundant metals may also benefit from $\mathrm{CO}_{2}$-enriched air.

\section{Acknowledgments}

This work was supported in part by Energy Materials Center at Cornell (award no. DE-SC0001086), and by award no. KUS-C1-018-02 made through King Abdullah University of Science and Technology (KAUST).

\section{References}

[1] C.-X. Zu, H. Li, Energy and Environmental Science 4 (2011) 2614.

[2] T. Ogasawara, A. Debarte, M. Holzapfel, P. Novak, P.G. Bruce, Journal of the American Chemical Society 128 (2006) 1390;

P.G. Bruce, S.A. Freunberger, L.J. Hardwick, J.-M. Tarascon, Nature Materials 11 (2012) 19.

[3] J.S. Lee, S.T. Kim, R. Cao, N.S. Choi, M. Liu, K.T. Lee, J. Cho, Advanced Energy Materials 1 (2011) 34

[4] E. Peled, D. Golodnitsky, H. Mazora, M. Goora, S. Avshalomov, Journal of Power Sources 196 (2011) 6835.

[5] Q. Sun, Y. Yang, Z.-W. Fu, Electrochemistry Communications 16 (2012) 22.

[6] D.P. Scharg, Science 315 (2007) 812.

[7] C. Gough, International Journal of Greenhouse Gas Control 2 (2008) 155.

[8] S.M. Benn, F.M. Orr, MRS Bulletin 33 (2008) 30.

[9] S. Xu, L.A. Archer, Cornell University Invention Disclosure 5889 (2012) "Metal- $\mathrm{CO}_{2}$ batteries for energy generation and carbon capture".

[10] K. Takechi, T. Shiga, T. Asaoka, Chemical Communications 47 (2011) 3463.

[11] D. Linden, T.B. Reddy, Handbook of Batteries, third ed. McGraw-Hill, 2002.

[12] S.K. Das, S. Xu, A.-H. Emwas, Y.Y. Lu, S. Srivastava, L.A. Archer, Energy and Environmental Science (2012), http://dx.doi.org/10.1039/c2ee22470d.

[13] E.G. Brame, S. Cohen, J.L. Margrave, V.W. Meloche, Journal of Inorganic and Nuclear Chemistry 4 (1957) 90.

[14] J.D. Wadhawana, P.J. Welforda, H.B. McPeak, C.E.W. Hahn, R.G. Compton, Sensors and Actuators B 88 (2003) 40.

[15] R. Ortiz, O.P. Marquez, J. Marquez, C. Gutierrez, Journal of Electroanalytical Chemistry 390 (1995) 99. 